\title{
A brief history of medical uniforms: from ancient history to the COVID-19 time
}

\section{Uma breve história de uniformes médicos: da história antiga aos tempos da COVID-19}

\author{
Victoria Rodrigues O’Donnelli'; lucas Albuquerque Chinelatto²iD; Cristina Rodrigues ${ }^{3}$; Flavio Carneiro Hojaij².
}

\begin{abstract}
A B S T R A C T
Medical Uniforms date back from medieval times. Nursing uniforms were based on nuns clothes whereas doctors used the famous "plague costumes" and black "frock" coats from about 15th to early 19th century. In latter half 19th century medical uniforms started to change. Nursing uniforms gradually lost their similarities to religious outfits. Doctors started to use white clothing. With great emphasis on hygiene and sanitation, the idea of personal protective equipment (PPE) started to evolve with William Stewart Halsted introducing the use of rubber gloves in 1889. In the 1960s-1970s it became more usual to wear green and blue 'scrubs in order to look for a greater contrast in clothing with the all-white hospital environment. In contemporary times, some specialties even stopped using specific uniforms, while others still use them. At the same time, PPE became more and more important, up to nowadays "plague costume" in the combat of the COVID-19 epidemics.
\end{abstract}

Keywords: Protective Clothing. Clothing. Coronavirus Infections. History. Occupational Health.

$T^{\text {no }}$ he medical profession, in one form or another, is understood to go as far back as ancient history, with examples being found in India, Saudi Arabia and Greece, as well as the Roman Empire and its evolution into the Byzantine Empire. The spread of Christianity through Europe also saw the introduction of hospitals and their various charitable purposes: caring for the sick, housing lepers, sheltering the poor, many of whom were pilgrims. These institutions were also seen as almshouses.

Nursing was typically carried out by nuns, and in some cases monks, while male physicians (women being excluded) established medical schools and developed treatments. It is unsurprising that early nurse uniforms originate from religious habits ${ }^{1}$. Long, dark tunics were worn with veils covering everything but their faces (Figure 1). These simple garments were not designed with hygiene in mind, instead they symbolised a nun's humility and rejection of material good ${ }^{1}$.

It is a common myth that the 'plague doctor costume' was a medieval invention. The French physician Charles de Lorme first developed the outfit during the Early Modern Period (which roughly lasted from the late 15th century to the early 19 th century) $)^{2}$. This thick leather costume, consisting of a hooded coat, boots, gloves and trousers, was designed to cover the entire body, while the beaked mask allowed the physician to breathe 'purified' air. The leather was wax coated in order to repel any bodily fluids during patient visits. Fragrant herbs and spices were placed within the beaked mask to filter the air and protect the wearer from 'miasmata' - noxious vapours thought to be infectious.

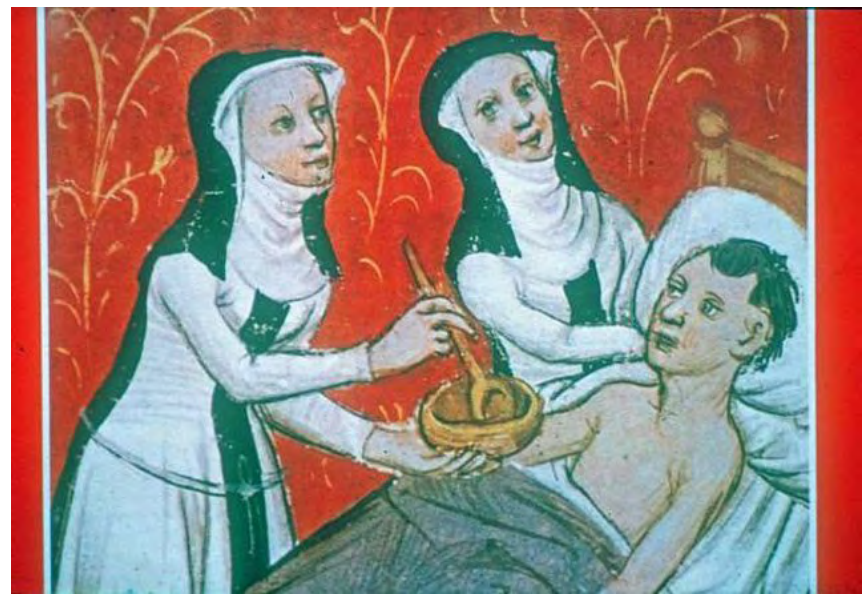

Figure 1. Archives of the Hospital de Notre Dame, Tournai, foundation charter of 1238.

1 - Fashion and Textile Museum, NIA - London - London District - Reino Unido 2 - University of São Paulo, Faculty of Medicine, Department of Surgery - São Paulo - SP - Brazil 3 - PLANISA, Administration - São Paulo - SP - Brazil 
The pious style of nurses' uniforms largely went untouched until Florence Nightingale established the Nightingale School of Nursing at St. Thomas' Hospital, in London, in 1860. Upon training at the Institution of Protestant Deaconesses in Kaiserswerth, Germany and her experience caring for soldiers during the Crimean War, Nightingale was able to introduce secular education for nurses. She insisted that 'no crinolines, polonaises, hair-pads etc.' should be worn as they would hinder movement and disrupt the calm atmosphere in the wards ${ }^{3}$. Any religious connotations were also deliberately removed, so that the focus was on nursing. However, dresses remained floor-length with aprons or pinafores worn on top. Caps helped secure hair away from their faces, while some still wore veils or scarves.

It was also during the latter half of the 19th century that doctors and surgeons began to wear white coats instead of 'frock' coats'. This followed a shift in which the profession began to formalise qualifications, teaching institutions and learned societies. By raising standards, new physicians were able to distance themselves as much as possible from barber-surgeons and 'quacks'. To signify respectability and their gentlemanly status, physicians wore dark, heavy 'frock' coats. Black was the most popular colour of choice, while some men chose to wear blue. They were also frequently referred to as 'blood and pus soaked' coats as a result of being stained during operations ${ }^{4}$. With greater emphasis on hygiene and sanitation by the end of the century, white coats, sterile gloves, gowns, and masks were soon introduced to pre-surgery rituals in operating theatres (Figure 2), with William Stewart Halsted introducing the use of rubber gloves in 1889. Masks and gloves would become even more commonplace after World War (WW) I and the Spanish flu epidemic of 1918. At this time, it can be noted that there were already some points very similar to nowadays.

It is important to highlight that nursing was one of the only professions available to women in the late 19th and early 20th centuries. As Canadian historian Christina Bates points out, their uniform was integral to their 'sense of belonging and self-respect'. Just as doctors and surgeons maintained respectability with their frock coats, so too did nurses with their uniforms ${ }^{3}$. Their utilitarian design also turned them into gentle, yet disciplined authority figures. From Red Cross volunteer uniforms during WWI to shorter sleeves, shorter hemlines and the proliferation of trousers after WWII, nurse uniforms transformed most dramatically throughout the 20th century.

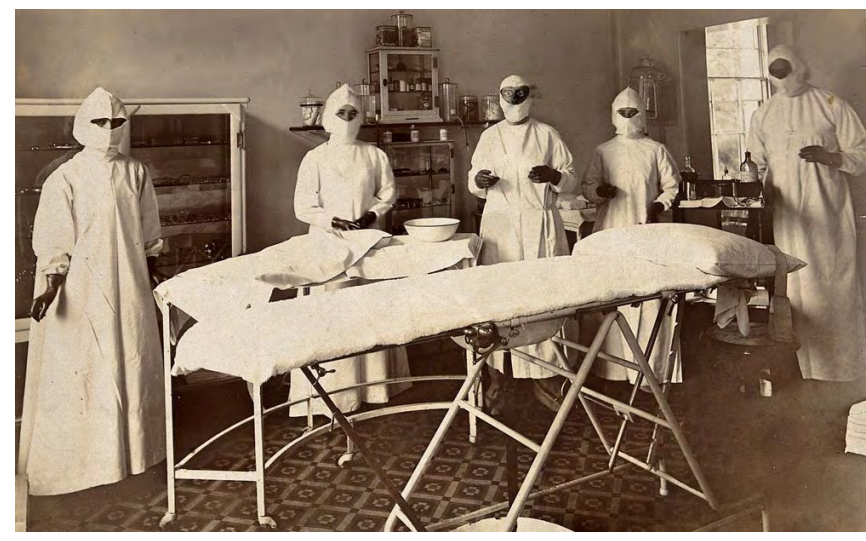

Figure 2. Operating theatre staff in gowns, masks and rubber gloves, Gloucester 1909. Wellcome Collection.

White uniforms for both doctors and nurses signified cleanliness, but the bright lights and all-white environment of operating theatres began to cause eyestrain for surgeons ${ }^{5}$. By the 1960s and 70s, most operating staff were wearing green uniforms to provide greater visual contrast. This style of surgical attire would evolve into what it is referred now as 'scrubs', so-called because the staff are required to scrub clean before operating ${ }^{6}$. These unisex outfits are comprised of blue or green cotton/polyester short-sleeved shirts and drawstring trousers, which are easy to launder and sterilise. Gowns, caps, face masks, latex gloves and rubber clogs are also worn as part of the full ensemble.

Nurses around the world, both men and women, now wear uniforms closely related to scrubs ${ }^{7}$. Coloured tunics can represent rank or specialism within a hospital, which may vary nationally and internationally. Recent years have seen white coats come under attack for reasons ranging from elitism and patient anxiety to contamination ${ }^{2}$. In some medical specialties, for example in psychiatry, it became a pattern to use regular or everyday outfits, and avoid using even a white coat in order to more closely relate to the patient.

At the same time, disposable personal protective equipment (PPE) became a trend and an important safety measurement in hospitals and in 
infection diseases wards ${ }^{8}$. For instance, nowadays, no person can enter a surgical centre without scrubs, mask and a cap. In relation to infectious diseases, the use of PPE is always mandatory and related to the current knowledge on their spread. For example, as it is seen in nowadays COVID-19 pandemic response, the antique 'plague doctor costume' corresponds to almost all the available PPE': cap, goggles, face shield, N95 mask (and sometimes a surgical mask over it), gown and gloves.

Many clinicians still advocate the use of white coats and the trust and compassion they evoke. The medical uniform not only inspires confidence within patients and pride for those who wear them, but they are a fundamental historical part of a profession which saves lives. Now, more than ever before!

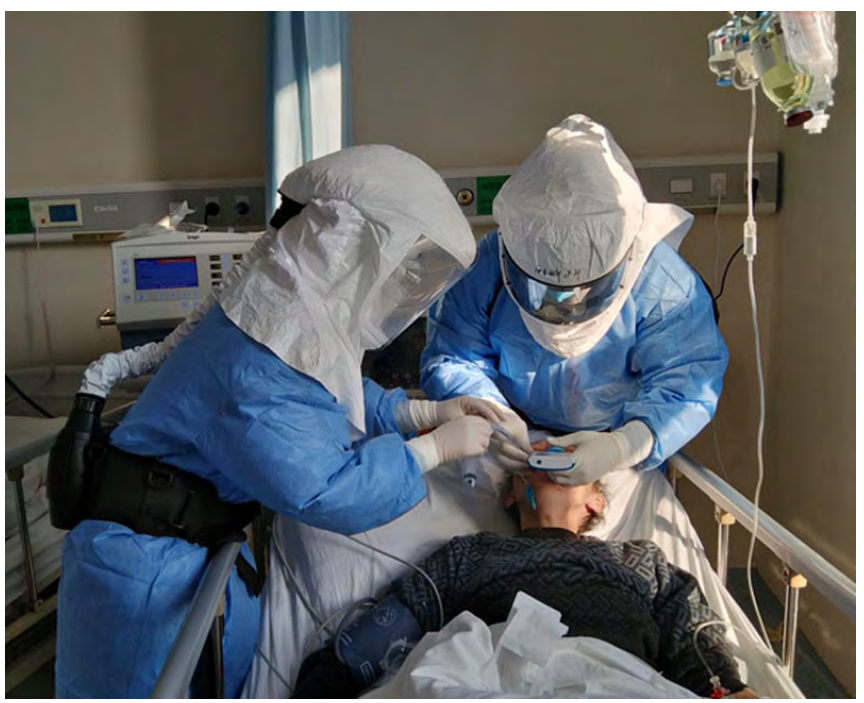

Figure 3. Two anesthesiologists performing endotracheal intubation on patient with COVID-1910.

\section{R E S U M O}

Uniformes da área médica datam desde os tempos medievais. Uniformes de enfermeiras eram baseados em roupas de freiras, enquanto o de médicos eram caracterizados pelas "vestimentas da praga" e fraques pretos de meados do século 15 até o início do século 19 . No final do século 19, os uniformes começaram a mudar. A vestimenta de enfermeiras perderam suas similaridades com vestes religiosas. Médicos começaram a usar roupas brancas. Com o aumento da ênfase em higiene e no sanitarismo, começa a evoluir a ideia do uso de equipamento de proteção individual (EPI), com William Stewart Halsted utilizando luvas de borracha pela primeira vez em 1889. Nas décadas de 1960 e 1970 começa a se tornar mais usual a adesão ao pijama cirúrgico verdes e azul como roupa hospitalar, devido ao contraste com o ambiente branco já presente. Na contemporaneidade, algumas especialidades deixaram de usar uniformes especificos, enquanto outras ainda a usam. Ao mesmo tempo, EPIs tornaram-se mais e mais importantes, até, hoje em dia, surgir as "vestimentas da praga" atualizadas para o combate da epidemia do COVID-19.

Palavras chave: Roupa de Proteção. Vestuário. Infecções por Coronavirus. História. Serviços de Saúde do Trabalhador.

\section{REFERENCES}

1. Bates C. A Cultural History of the Nurses's Uniform. Gatineau: QC: Canadian Museum of Civilization Corporation; 2012.

2. Tubino P, Alves E. Evolução Histórica da Vestimenta do Médico. Rev Med Pesq. 2009;1(2):87-102.

3. Parkins I, Sheehan EM, Rita F. Cultures of Feminity in Modern Fashion. Durham: University of New Hampshire Press; 2012.

4. Hardy S, Corones A. Dressed to heal: the changing semiotics of surgical dress. Fash Theory. 2015;20(1):27-49.

5. Surgeons and surgical spaces. Science Museum [Internet]. Science Museum Group. [cited 2020 May 5]. Available from: https://www.sciencemuseum. org.uk/objects-and-stories/medicine/surgeons-and- surgical-spaces/

6. Isaac S. Frock coats to scrubs: a story of surgical attire [Internet]. Royal College of Surgeons of England. [cited 2020 May 5]. Available from: https://www. rcseng.ac.uk/library-and-publications/library/blog/ frock-coats-to-scrubs/

7. Wall BM. History of hospitals [Internet]. University of Pennsylvania School of Nursing. [cited 2020 May 5]. Available from: https://www.nursing.upenn.edu/ nhhc/nurses-institutions-caring/history-of-hospitals/

8. Honda H, Iwata K. Personal protective equipment and improving compliance among healthcare workers in high-risk settings. Curr Opin Infect Dis. 2016;29(4):400-6.

9. Sayburn A. Covid-19: PHE upgrades PPE advice for all patient contacts with risk of infection. BMJ. 2020 Apr 3;m1391. 
10. Zhang HF, Bo L, Lin $Y$, Li FX, Sun $S$, Lin $H B$, et al. Response of Chinese anesthesiologists to the COVID-19 outbreak. Anesthesiology. 2020;132(6):1333-8.
Received in: 30/04/2020

Accepted for publication: 06/05/2020

Conflict of interest: no.

Funding source: none.
Mailing address:

Lucas Albuquerque Chinelatto

E-mail: I.chinelatto@fm.usp.br

(c) (i) 